\title{
CONCERTED INTERNATIONAL RESPONSE TO CONTROL ONGOING CHOLERA EPIDEMIC IN ZIMBABWE
}

\author{
Editorial team (eurosurveillance@ecdc.europa.eu) ${ }^{1}$ \\ 1. European Centre for Disease Prevention and Control, Stockholm, Sweden
}

Zimbabwe is grappling with a cholera outbreak of unprecedented proportions. As of 9 December, 16141 suspected cases of cholera have been recorded since August this year, with 775 resultant deaths and a case fatality rate of $4.8 \%$. Cases have been reported in two-thirds of the country's 62 districts [1].

This largest cholera outbreak in the modern history of Zimbabwe is unfolding against a background of a complex political and economic crisis, with a deteriorating healthcare system weakened by lack of resources and staff strikes. A major triggering factor has been the lack of clean water because the state-run water company has run out of aluminium sulphate, a chemical used for water purification, and often water cannot be boiled because of erratic electricity supplies.

There is also a danger of cholera spreading into neighbouring countries. As of 2 December, 468 cholera cases and nine related deaths had been recorded by South African health authorities, most of them near the border to Zimbabwe [2].

On 3 December, the Zimbabwean Minister of Health and Child Welfare launched an appeal for international humanitarian aid. This has met with a widespread response from a host of diverse organisations such as the World Health Organization (WHO), the United Nations Children's Fund (UNICEF), the International Organization for Migration, OXFAM, Médecins du Monde, Médecins sans Frontières, the international non-governmental organization GOAL, Save the Children, and many others. The participants have established a comprehensive and coordinated operational plan in the hope of bringing the outbreak rapidly under control.

WHO is establishing a cholera control and command centre and seeking donor support for its cholera response plan. Regarding the spread of cholera, WHO does not recommend any special restrictions on travel or trade to or from affected areas, but encourages neighbouring countries to strengthen their active surveillance and preparedness systems [3].

\section{References}

1. World Health Organization. Health system problems aggravate cholera outbreak in Zimbabwe. News Release. 10 December 2008. Available from: http://www. who.int/mediacentre/news/releases/2008/pr49/en/index.html

2. World Health Organization. Zimbabwe Health Cluster Bulletin No. 1. 5 December 2008. Available from: http://www.who.int/csr/don/2008_12_02/en/index.html

3. World Health Organization. Cholera in Zimbabwe. Epidemic and Pandemic Alert and Response (EPR). 2 December 2008. Available from: http://www.who.int/csr/ don/2008_12_02/en/index.html

This article was published on 11 December 2008.

Citation style for this article: Editorial team. Concerted international response to control ongoing cholera epidemic in Zimbabwe. Euro Surveill. 2008;13(50):pii=19064. Available online: http://www.eurosurveillance.org/ViewArticle.aspx?ArticleId=19064 